\title{
Konsep Notaris Mayantara Menghadapi Tantangan Persaingan Global
}

\author{
Habib Adjie* \\ Program Kenotariatan, Universitas Narotama \\ Jalan Klampis Semalang VII No. 33, Kota Surabaya, 60117, Indonesia
}

\begin{abstract}
ABSTRAK
Tujuan penelitian ini menjelaskan konsep notaris mayantara dalam menghadapi tantangan persaingan global. Metode penelitian ini hukum normatif atau penelitian hukum doktrinal dengan pendekatan hukum klinis. Berdasarkan hasil penelitian dapat dijelaskan bahwa selain merujuk pada UUJN-P ditegaskan kewenangan notaris juga berdasarkan undangundang lainnya. Kewenangan lain yang diatur dalam peraturan perundang-undangan, antara lain kewenangan mensertifikasi transaksi yang dilakukan secara elektronik, membuat akta ikrar wakaf, dan hipotek pesawat terbang. Pengaturan notaris Indonesia berdasarkan UUJN/UUJN-P dan peraturan perundang-undangan lainnya mengatur bahwa penghadap dalam arti fisik kertas (secara fisik tanpa media apapun ada dihadapan notaris). Dengan demikian, dokumen yang diperlukan masih harus diperlihatkan fisiknya. Kesimpulan penelitian ini bahwa konsep notaris mayantara menghendaki notaris dalam menjalankan tugas atau kewenangannya berbasis teknologi informasi khususnya dalam pembuatan akta. Dalam konsep ini, bahwa menghadap secara fisik atau langsung berhadapan tidak diperlukan. Tetapi, bisa menggunakan media pandang dengar, tanpa batas kota/provinsi bahkan tanpa batas wilayah negara (borderless). Dengan konsep ini, tidak perlu menghadap langsung dengan cara datang ke kantor notaris. Dalam pengembangan lebih lanjut, identitas diri penghadap tidak perlu diperlihatkan secara fisik, demikian pula dokumen yang diperlukan cukup dengan cara mengunduhnya. Dalam konsep ini, bukan hanya tanda tangan yang harus dilakukan secara elektronik, tapi juga dokumen dalam membuat akta.
\end{abstract}

\section{Kata Kunci: Notaris, Akta, Elektronik}

\begin{abstract}
The purpose of this study is to explain the notary concept of mayantara in facing the challenges of global competition. This research method is normative law or doctrinal law research with clinical law approach. Based on the results of research can be explained that in addition to referring to UUJN-P affirmed the authority of notary also based on other laws. Other authorities regulated in legislation, including the authority to certify transactions conducted electronically, make deeds pledge waqf, and mortgage aircraft. Indonesian notary arrangements under UUJN / UUJN-P and other laws and regulations stipulate that the confrontation in the physical sense of the paper (physically without any media present before the notary). Thus, the necessary documents must still be shown physically. The conclusion of this research that the notary concept mayantara want notarial in carrying out duty or authority based on information technology especially in making deed. In this concept, that facing physically or directly face to face is not required. But,
\end{abstract}

*Penulis Korespondensi

E-mail: Adjieku61@gmail.com 
can use the media view of hearing, without limits city / province even without borderless country (borderless). With this concept, no need to face directly by way of coming to the notary's office. In further development, self-identity does not need to be physically demonstrated, nor is the document required simply by downloading it. In this concept, it is not just a signature to be done electronically, but also a document in making the deed.

\section{Keywords: Notary, Deed, Electronic}

\section{Pendahuluan}

Globalisasi merupakan era yang harus dijalani sebagai konsekuensi hidup yang saling membutuhkan. Era tersebut tidak dapat dihindari supaya tidak terkucilkan dari kemajuan dunia. Menurut Susilo Bambang Yudhoyono bahwa "suka atau tidak suka, globalisasi mendatangkan peluang, tantangan, kebaikan, keburukan, kompetisi, dan kerja sama. Karena itu, mari cerdas dan bijak mendapatkan peluang, bekerja sama dari globalisasi". ${ }^{1}$ Oleh karena itu, bangsa Indonesia mau tidak mau, siap tidak siap, harus mempersiapkan diri dalam globalisasi. Pada akhirnya, globalisasi memberikan dampak (impact) pada bidang atau berbagai segmen kehidupan manusia, karenanya akan terbuka peluang (opportunity) dan tantangan (challenge). Salah satu peluang tersebut, yaitu dalam bidang perdagangan jasa (service trade).

Untuk memasuki era tersebut tentu harus dipersiapkan perangkat lunaknya (software). Dalam kaitan ini, sumber daya manusia (SDM) harus dipersiapkan, sehingga peluang di era globalisasi dapat diraih. Dengan demikian, peluang tersebut tidak hanya dimanfaatkan asing, meskipun hal tersebut suatu yang wajar dalam Organisasi Perdagangan Dunia/World Trade Organization (WTO) dengan pasar terbuka.
Ketika Perjanjian Putaran Uruguay diselesaikan pada tanggal 15 Desember 1994 yang secara keseluruhan ditandatangani di Marakesh (Maroko) pada tanggal 15 April 1995. Kemudian dilanjutkan dengan pembentukan WTO dalam bentuk Agreement Establishing The Multilateral Trade Organization, sehingga negara yang turut serta didalamnya mau tidak mau harus menaati Perjanjian Uruguay tersebut. Dengan demikian, setiap warga negara dan badan hukum negara yang terlibat didalamnya (termasuk Indonesia), terutama dalam dunia usaha (bisnis) wajib menaati substansi Putaran Uruguay tersebut.

Ada 4 (empat) bidang hukum yang berdampak langsung dari Perjanjian Uruguay, yaitu penanaman modal, perdagangan jasa, perdagangan hak milik intelektual, dan hukum persaingan. Bidang-bidang tersebut harus diimplementasikan lebih lanjut dalam perundang-undangan nasional dengan memperhatikan prinsip perdagangan bebas, seperti transparansi, akses yang adil ke semua pasar untuk semua pelaku ekonomi dan tidak ada hambatan tarif.

Terhadap substansi Perjanjian Putaran Uruguay tersebut, ada negara yang tidak setuju. Ketidaksetujuan itu karena terlalu banyak memberikan keuntungan negara maju, misalnya harus membuka pasar produk negara

1Sambutan Presiden Susilo Bambang Yudhoyono dalam pembukaan Gelar Produk Kerajinan Indonesia, Kompas, Kamis, 23 Maret 2006, hlm. 1. 
anggota WTO lainnya. Hal tersebut akan menjadi masalah besar, ketika negara yang bersangkutan tidak mempunyai produk kompetitif. Negara yang tidak mempunyai produk akan menjadi "pasar" dari negara lain. Untuk mensiasatinya, diputuskan perdagangan bebas dalam WTO dilakukan secara bertahap pada kawasan tertentu. Pada tahun 2020 perdagangan bebas dalam WTO harus terlaksana dengan penuh.

Rubens Ricupero sebagai Sekretaris Jenderal pada United Nations Conference on Trade and Development (UNCTAD) 1996 mendefinisikan globalisasi sebagai: " $A$ process producers ang investors increasingly behave as if the world economy consisted of a single market ang production area with regional or national subsector, rather than a set a national economies linked by trade and the investment flow". ${ }^{1}$ Berdasarkan definisi globalisasi tersebut maka globalisasi sebagai suatu proses membuana meliputi 3 (tiga) bidang, yaitu ${ }^{2}$

1. globalisasi of trade;

2. globalisasi of production;

3. globalisasi of financial markets.

Terkait 3 (tiga) bidang tersebut maka pasar harus terbuka, berarti ada liberalisasi, ${ }^{3}$ atau the removal of barriers (such as tariffs or national control) in order to create a free markets in goods, service or finance. Liberalisasi bukan berarti bebas dan terbuka dalam segala bidang ataupun menghilangkan batas wilayah negara (borderless) atau kedaulatannya. Kekhawatiran seperti itu bukan tanpa alasan, karena negara industri kuat dan menguasai perekonomian dunia, seperti Amerika Serikat, Jepang dapat saja memaksakan kehendaknya kepada negara lain untuk membuka pasarnya. Jika negara bersangkutan mengikuti kehendak Amerika Serikat dan Jepang serta negara maju lainnya maka sudah pasti tidak berdaya.

Agar liberalisasi tidak berdampak negatif maka diperlukan perangkat privatisasi, deregulasi dan debirokratisasi oleh negara (pemerintah) sebagai pemain globalisasi perdagangan. Luasnya cakupan liberalisasi tidak hanya meliputi barang (goods), tapi juga jasa (services) sehingga diperlukan berbagai persiapan yang baik.

Batasan pengertian jasa ditentukan dalam Pasal 1 Paragraph 3 (b) GATS, yaitu services includes any sector except servic applied in the exercise of governmental authority. ${ }^{4}$ Jika diteliti lebih lanjut, tidak ada rincian mengenai sektor jasa yang menjadi komoditas bebas WTO, hanya ada perkecualian, yaitu jasa yang menjadi kewenangan pemerintah (governmental authority).

Pedoman untuk mengetahui sektor jasa yang dimaksud Pasal 1 Paragraph 3 (b) GATS dapat dilihat dari ketentuan GATT tahun 1991 tentang service sectoral classification list. Dalam daftar tersebut ditentukan sektor-sektor bidang jasa, antara lain:

1. Business service;

2. Communication service;

3. Construction service;

4. Distribution service;

${ }^{1}$ Panos Briefing, Globalization and Employment, New Opportunities, Real Threats, London Nomor 33, May 1999, hlm. 3.

2Ibid, hlm. 1.

${ }^{3}$ lbid.

${ }^{4}$ GATS merupakan salah satu bagian dari GATT yang mengatur perdagangan jasa. Kemudian WTO sebagai pengurus dari GATT telah pula membentuk dewan khusus dalam struktur WTO yang khusus untuk menangani masalah jasa, yaitu council for trade in services. 
5. Eduacation service;

6. Environmental service;

7. Financial service;

8. Health related and social service;

9. Cultural and sporting service.

Kemudian bentuk penyedia jasa yang dapat dilakukan dalam Annex 1B GATS, Pasal 1 Paragraph 2 ada 4 (empat), yaitu

1. From the territory of one member into the territory of any other member.

2. In the territory of one member to the service consumer of any other member.

3. By a service supplier of one member, through commercial presence in the territory of any other member.

4. By a service supplier of one member, through presence of natural person of a member in the territory of any other member.

Sektor jasa dalam globalisasi akan menjadi komoditas dengan daya jual tinggi dan merupakan industri yang akan diminati maka Indonesia sebagai anggota GATT/WTO tentu harus membuka pasarnya. Akibatnya, bidang jasa akan timbul peluang sekaligus tantangan bagi SDM dan hukum di bidang perdagangan jasa.

Indonesia yang sekarang berada dalam era globalisasi juga dihadapkan pada perkembangan teknologi informasi dan komunikasi harus menyadari bahwa informasi tersebut sangat berperan dan berkontribusi terhadap pembangunan ekonomi, sosial, dan budaya. Selain itu, kemajuan teknologi informasi dan komunikasi juga mempengaruhi kondisi sosial masa mendatang, seperti sistem pelayanan medis, pelayanan pendidikan, pelayanan administrasi pemerintahan dan berbagai aspek kehidupan lainnya. ${ }^{5}$ Kemajuan teknologi informasi dan komunikasi juga akan berdampak pada peran notaris di masa depan sesuai tuntutan zaman yang berkembang pesat.

Mengimbangi tuntutan zaman tersebut maka Indonesia harus mempersiapkan SDM dan hukum di bidang perdagangan jasa agar tidak menjadi penonton di negeri sendiri. Sebagai contoh jasa bidang kesehatan, seperti dokter dan perawat mulai tahun 2003 boleh berpraktik di Indonesia. Rumah sakit asing yang akan dan telah berdiri di Indonesia boleh membawa teknologi dan tenaga medisnya sendiri. Kemudian profesi akuntan, advokat (lawyer) dengan perjanjian waralaba (franchise) telah membuka kantor di Indonesia dengan standar pelayanan internasional. Untuk notaris dan Pejabat Pembuat Akta Tanah (PPAT) secara institusional belum dapat (mungkin tidak dapat) dijabat oleh warga negara asing, karena jabatan notaris dan PPAT merupakan pelaksana sebagian kewenangan pemerintah dalam bidang hukum perdata. ${ }^{6}$ Dengan demikian, notaris dan atau PPAT merupakan perkecualian, yaitu jasa yang menjadi kewenangan pemerintah (governmental authority).

Notaris Indonesia sampai saat ini masih menggunakan ketentuan hukum yang belum berubah dalam pembuatan akta, khususnya mengenai tindakan menghadap, pembacaan, penandatanganan serta penggunaan meterai. Dalam era tanpa batas ini (borderless) semua sekat ataupun yang membatasi pergerakan

${ }^{5}$ Mariam Darus Badrulzaman, Mendambakan Kelahiran Hukum Saiber (Cyber Law) di Indonesia, Makalah disampaikan dalam Pidato Purna Bhakti, Medan, 2001, hlm. 6.

${ }^{6}$ Bagir Manan, Hukum Positif Indonesia, (Yogyakarta: UII Press, 2004), hlm. 15. 
informasi dapat diakses dengan maksud dan tujuan tertentu. Notaris pun harus siap memberikan pelayanan sesuai kemajuan teknologi informasi dan komunikasi. Untuk itu, terlebih dahulu harus dibuat konsep notaris dalam menjalankan jabatannya seiring kemajuan teknologi informasi dan komunikasi dalam konteks global.

Kemajuan teknologi informasi dan komunikasi dalam konteks global merupakan peluang dan tantangan yang harus menjadi perhatian serius. Peluang dan tantangan tersebut harus dijawab dengan meningkatkan kualitas dan kuantitas SDM serta hukum yang mengatur hal tersebut, sehingga Indonesia dapat bersaing sehat dalam perdagangan jasa khususnya berkaitan dengan peran notaris.

Dalam penelusuran penulis ada beberapa penelitian sebelumnya terkait peran notaris, tetapi tidak menyinggung peran notaris dalam menghadapi tantangan global. Ahmad Crusade Giri Brata dalam penelitiannya berjudul Analisis Konsep Notaris Mayantara dan Otentisitas Aktanya Terkait Undang-Undang Nomor 40 Tahun 2007 tentang Perseroan Terbatas menjelaskan konsep notaris mayantara terkait Undang-Undang Nomor 40 Tahun 2007 tentang Perseroan Terbatas. Dalam konteks itu, mengharuskan notaris hadir dalam Rapat Umum Pemegang Saham (RUPS) Luar Biasa melalui media elektronik. Tindak lanjutnya, akta berita acara RUPS Luar Biasa dibuat dan ditandatangani secara elektronik oleh para pemegang saham, para saksi dan notaris. Autentisitas akta notaris mayantara atau akta berita acara RUPS Luar Biasa melalui media elektronik menjadi tidak autentik karena telah melanggar ketentuan Pasal 1 angka 7 juncto Pasal 16 Ayat (1) huruf M juncto Penjelasan Pasal 16 Ayat (1) huruf M Undang-Undang Nomor 2 Tahun 2014 tentang Perubahan Atas Undang-Undang Nomor 30 Tahun 2004. Dalam penelitiannya, menyarankan dilakukan harmonisasi khususnya Pasal 1 angka 7 juncto Pasal 16 Ayat (1) huruf $M$ juncto Penjelasan Pasal 16 Ayat (1) huruf M Undang-Undang Nomor 2 Tahun 2014 tentang Perubahan Atas Undang-Undang Nomor 30 Tahun 2004. Pasal tersebut berkaitan dengan penerimaan dari penandatanganan akta secara elektronik, akta autentik dalam bentuk akta elektronik, kehadiran melalui media elektronik, dan pembacaan akta melalui media elektronik. ${ }^{7}$

Penelitian Fahma Rahman Wijanarko menjelaskan kekuatan pembuktian akta notaris terhadap pemberlakuan cyber notary berdasarkan Undang-Undang Jabatan Notaris dan hukum positif di Indonesia tidak memiliki pembuktian yang sempurna layaknya akta autentik. Seharusnya, terkait akta notaris terhadap pemberlakuan cyber notary harus merubah Pasal 1868 Kitab Undang-Undang Hukum Perdata (KUHPerdata), Undang-Undang Jabatan Notaris dan Undang-Undang Informasi dan Transaksi Elektronik. ${ }^{8}$

Penelitian Tiska Sundani berjudul Analisis Hukum atas Penggunaan dan Pembuatan Akta Notaris Secara Elektronik menjelaskan pembuatan akta elektronik memerlukan harmonisasi hukum terkait Pasal 15, paragraf

${ }^{7}$ Ahmad Crusade Giri Brata, Analisis Konsep Notaris Mayantara dan Otentisitas Aktanya Terkait UndangUndang Nomor 40 Tahun 2007 tentang Perseroan Terbatas, Tesis Program Pascasarjana Program Magister Kenotariatan, Universitas Dipenogoro, 2014, hlm. 5.

${ }^{8}$ Fahma Rahman Wijanarko, Tinjauan Yuridis Pemberlakuan Cyber Notary di Indonesia Berdasarkan Undang-Undang Nomor 2 Tahun 2014 tentang Perubahan atas Undang-Undang Nomor 30 Tahun 2004 tentang Jabatan Notaris, Jurnal Repertorium, Volume 2, Nomor 2, Tahun 2015, hlm. 7. 
3 Undang-Undang Jabatan Notaris dan Pasal 17 Undang-Undang Perseroan Terbatas. Pembuatan akta notaris secara elektronik dimaksud, seperti pencatatan akta fidusia, pencatatan notaris, amandemen anggaran dasar badan hukum, dan sebagainya. ${ }^{9}$

Komang Febrinayanti Dantes dengan penelitian berjudul Kekuatan Hukum Akta Notaris Berkenaan dengan Penandatanganan Rapat Umum Pemegang Saham (RUPS) Perseroan Terbatas Melalui Media Tele-konferensi, menjelaskan kekuatan hukum penandatanganan akta notaris elektronik melalui media telekonferensi sah dikaitkan dengan Pasal 11 Undang-Undang Informasi Teknologi Elektronik. Keabsahan tersebut dengan syarat pemegang saham ketika melakukan RUPS via telekonferensi harus berada di wilayah Republik Indonesia sebagaimana diatur Pasal 76 Ayat (3) dan Ayat 4 Undang-Undang Perseroan Terbatas. Tanggung jawab notaris dalam penandatanganan elektronik memberi legitimasi hukum yang kuat atas akta berita acara RUPS, karena tanda tangan yang dibubuhkan secara elektronik dalam RUPS telah mendapatkan sertifikat dari lembaga sertifikasi yang menjamin keabsahan tandatangan elektronik. ${ }^{10}$

Triyanti penelitiannya berjudul Kekuatan Pembuktian Dokumen Elektronik Sebagai Pengganti Minuta Akta Notaris menjelaskan pendapat para ahli hukum dan beberapa yurisprudensi tentang kekuatan pembuktian terhadap alat bukti elektronik dapat dipersamakan atau dianalogikan dengan kekuatan pembuktian fotokopi. Kekuatan pembuktian fotokopi itu ada pada surat atau akta aslinya. Apabila alat bukti berupa bukti fotokopi yang tidak disertai surat atau akta aslinya maka harus diikuti dengan alat bukti lain, seperti keterangan saksi atau saksi ahli. Dengan demikian, kekuatan pembuktian dokumen elektronik tidak dapat dikatakan sebagai pengganti dari akta autentik. Artinya, nilai kekuatan pembuktian alat bukti elektronik masih sebagai alat bukti biasa, tidak dapat berdiri sendiri dalam mencukupi batas minimal pembuktian, walaupun dokumen elektronik tersebut adalah hasil out put atau hasil cetakan (fotokopi) dari sebuah akta autentik sekalipun. ${ }^{11}$

Memperhatikan hasil penelitian terdahulu tersebut jelaslah tidak berkaitan dengan peran notaris dalam menghadapi tantangan global, sehingga penelitian yang penulis lakukan merupakan suatu kebaruan (novelty). Oleh karena itu, penelitian ini menjadi penting dilakukan karena akan memberikan konstribusi dalam pengetahuan. Adapun permasalahan dalam penelitian ini berangkat dari pertanyaan bagaimana konsep notaris mayantara dalam menghadapi tantangan persaingan global? Untuk menjawab pertanyaan tersebut penulis mengunakan pendekatan hukum normatif. Tujuan yang diharapkan dari penelitian ini untuk menjelaskan konsep notaris mayantara dalam menghadapi tantangan persaingan global.

\section{Metode Penelitian}

Penelitian ini adalah penelitian hukum normatif atau penelitian hukum doktrinal dengan menfokuskan dari hukum klinis, yaitu untuk

${ }^{9}$ Tiska Sundani, Analisis Hukum atas Penggunaan dan Pembuatan Akta Notaris Secara Elektronik, Premise Law Jurnal, Volume 1, Tahun 2017, hlm. 16.

${ }^{10}$ Komang Febrinayanti Dantes, Kekuatan Hukum Akta Notaris Berkenaan dengan Penandatanganan Rapat Umum Pemegang Saham (RUPS) Perseroan Terbatas Melalui Media Telekonferensi, Tesis, Universitas Udayana, 2015, hlm. ix.

${ }^{11}$ Triyanti, Kekuatan Pembuktian Dokumen Elektronik Sebagai Pengganti Minuta Akta Notaris, Jurnal Repertorium, Volume II, Nomor 2 Juli - Desember 2015, hlm. 20. 
menemukan hukum yang akan diterapkan untuk menyelesaikan perkara atau masalah tertentu (in-concreto). Sebagai penelitian hukum normatif maka sumber data yang dipergunakan berupa data sekunder, terdiri dari bahan hukum primer dan bahan hukum sekunder. Analisis data penelitian secara secara kualitatif, yakni membandingkan atau menerapkan peraturan perundang-undangan yang berlaku, pendapat para sarjana (doktrin) serta teori-teori hukum lainnya. Kesimpulan penelitian secara deduktif, yakni penarikan kesimpulan diawali dari yang bersifat umum kepada yang bersifat khusus.

\section{Pembahasan}

\section{Konsep Notaris Mayantara Menghadapi Tantangan Persaingan Global}

Jabatan notaris dikehendaki hukum untuk membantu dan melayani masyarakat yang membutuhkan alat bukti tertulis autentik mengenai keadaan, peristiwa atau perbuatan hukum. Orang yang diangkat menjadi notaris harus semangat melayani masyarakat. Atas pelayanan tersebut, notaris berhak menerima honorarium. Notaris tidak akan berarti jika tidak ada masyarakat yang membutuhkannya, meskipun ia diberikan wewenang jabatan oleh hukum.

Setiap wewenang jabatan harus ada batasan agar berjalan baik dan tidak bertabrakan. Jika seorang pejabat (notaris) melakukan tindakan di luar wewenang maka dapat dikategorikan sebagai perbuatan melanggar wewenang. ${ }^{12}$ Menurut Philipus $M$. Hadjon ada istilah kewenangan dan wewenang sejajar dengan istilah hukum dalam Bahasa Belanda, yaitu bevoegdheid. Ada sedikit perbedaan antara ketiga istilah tersebut.
Perbedaannya terletak pada karakter hukumnya. Istilah bevoegdheid digunakan baik dalam konsep hukum publik maupun konsep hukum privat. Dalam hukum Indonesia istilah kewenangan atau wewenang seharusnya digunakan dalam konsep hukum publik.

Dalam Pasal 1 angka 1 dan Pasal 15 Undang-Undang Republik Indonesia Nomor 2 Tahun 2014 tentang Perubahan Atas UndangUndang Nomor 30 Tahun 2004 tentang Jabatan Notaris (Lembaran Negara Republik Indonesia Tahun 2014 Nomor 3, Tambahan Lembaran Negara Republik Indonesia Nomor 5491) selanjutnya UUJN-P ditentukan kewenangan notaris, yaitu

Pasal 1

1. Notaris adalah pejabat umum yang berwenang untuk membuat akta autentik dan memiliki kewenangan lainnya sebagaimana dimaksud dalam UndangUndang ini atau berdasarkan undangundang lainnya.

Pasal 15:

(1) Notaris berwenang membuat akta autentik mengenai semua perbuatan, perjanjian, dan penetapan yang diharuskan oleh peraturan perundang-undangan dan/atau yang dikehendaki oleh yang berkepentingan untuk dinyatakan dalam akta autentik, menjamin kepastian tanggal pembuatan akta, menyimpan akta, memberikan grosse, salinan dan kutipan akta, semuanya itu sepanjang pembuatan akta itu tidak juga ditugaskan atau dikecualikan kepada pejabat lain atau orang lain yang ditetapkan oleh undang-undang.

(2) Selain kewenangan sebagaimana dimaksud pada Ayat (1), notaris berwenang pula:

${ }^{12}$ Philipus M. Hadjon, Tentang Wewenang, Jurnal Yuridika, Fakultas Hukum Universitas Airlangga, Nomor 5 dan 6, Tahun XII, September-Desember 1997, hIm. 1. 
a. mengesahkan tanda tangan dan menetapkan kepastian tanggal surat di bawah tangan dengan mendaftar dalam buku khusus.

b. membukukan surat di bawah tangan dengan mendaftar dalam buku khusus.

c. membuat kopi dari asli surat di bawah tangan berupa salinan yang memuat uraian sebagaimana ditulis dan digambarkan dalam surat yang bersangkutan.

d. melakukan pengesahan kecocokan fotokopi dengan surat aslinya.

e. memberikan penyuluhan hukum sehubungan dengan pembuatan akta.

f. membuat akta yang berkaitan dengan pertanahan atau

g. membuat akta risalah lelang.

(3) Selain kewenangan sebagaimana dimaksud pada Ayat (1) dan Ayat (2), notaris mempunyai kewenangan lain yang diatur dalam peraturan perundang-undangan.

Substansi pasal-pasal tersebut menegaskan kewenangan notaris. Pasal 1 angka 1 UUJN-P, selain merujuk pada UUJN-P ditegaskan kewenangan notaris juga berdasarkan undang-undang lainnya. Pada Pasal 15 Ayat (1) dan (3) notaris mempunyai kewenangan lain yang diharuskan atau diatur dalam peraturan perundang-undangan. Penjelasan Pasal 1 angka 1 dan Pasal 15 Ayat (1) hanya disebutkan cukup jelas. Penjelasan Pasal 15 Ayat (3) menjelaskan bahwa yang dimaksud dengan "kewenangan lain yang diatur dalam peraturan perundang-undangan", antara lain kewenangan mensertifikasi transaksi yang dilakukan secara elektronik (cyber notary), membuat akta ikrar wakaf, dan hipotek pesawat terbang.

Menurut George Whitecross Patton alat bukti dapat berupa oral (words spoken by a witness in court) dan documentary (the production of a admissible documents) atau material (the production of a physical res other than a document). ${ }^{13}$ Alat bukti yang sah atau diterima dalam suatu perkara (perdata), pada dasarnya terdiri dari ucapan dalam bentuk keterangan saksi-saksi, pengakuan, sumpah dan tertulis berupa tulisan-tulisan yang mempunyai nilai pembuktian. Dalam perkembangan alat bukti sekarang (untuk perkara pidana dan perdata), alat bukti elektronik atau yang terekam atau yang disimpan secara elektronik sebagai alat bukti yang sah dalam persidangan pengadilan sebagaimana diatur dalam Undang-Undang Nomor 11 Tahun 2008 tentang Informasi Transaksi Elektronik (selanjutnya UU ITE).

Menurut Pasal 5 UU ITE, menegaskan bahwa:

(1) Informasi elektronik dan/atau dokumen elektronik dan/atau hasil cetaknya merupakan alat bukti hukum yang sah.

(2) Informasi elektronik dan/atau dokumen elektronik dan/atau hasil cetaknya sebagaimana dimaksud pada Ayat (1) merupakan perluasan dari alat bukti yang sah sesuai dengan hukum acara yang berlaku di Indonesia.

(3) Informasi elektronik dan/atau dokumen elektronik dinyatakan sah apabila menggunakan sistem elektronik sesuai dengan ketentuan yang diatur dalam undang-undang ini.

${ }^{13}$ George Whitecross Patton, A Text-Book of Jurisprudence, (Oxford: at the Clarendon Press, second edition, 1953), hlm. 481. 
(4) Ketentuan mengenai informasi elektronik dan/atau dokumen elektronik sebagaimana dimaksud pada Ayat (1) tidak berlaku untuk:

a. surat yang menurut undangundang harus dibuat dalam bentuk tertulis; dan

b. surat beserta dokumennya yang menurut undang-undang harus dibuat dalam bentuk akta notaril atau akta yang dibuat oleh pejabat pembuat akta.

Dengan meningkatnya aktivitas elektronik maka alat pembuktian yang dapat digunakan secara hukum harus meliputi informasi atau dokumen elektronik untuk memudahkan pelaksanaan hukumnya. Selain itu, hasil cetak dari dokumen atau informasi tersebut harus dapat dijadikan bukti yang sah secara hukum. Untuk memudahkan pelaksanaan penggunaan bukti elektronik (baik dalam bentuk elektronik maupun hasil cetak) maka bukti elektronik dapat disebut sebagai perluasan alat bukti yang sah sesuai dengan hukum acara yang berlaku di Indonesia sebagaimana diatur pada Pasal 5 UU ITE. ${ }^{14}$

Hasil cetak dan print out dari dokumen elektronik atau fotokopi jika tidak dihadirkan aslinya maka tidak ada tolok ukur keabsahan dan keasliannya. Dengan demikian, hakim pemeriksa perkara akan mengalami kesulitan, karena begitu banyaknya dokumen yang harus diperiksa dan tidak ada tolok ukur untuk meyakinkan bahwa bukti atau dokumen elektronik itu benar adanya. Begitu pula dengan salinan akta, apabila terhadap salinan tersebut tidak dapat ditunjukan aslinya kepada hakim maka para pihak wajib membuktikan salinan- salinan tersebut telah termasuk dan sesuai dengan kriteria sebagai salinan yang mempunyai kekuatan hukum yang sama dengan aslinya sebagaimana diuraikan dalam dalam Pasal 1889 Ayat (1) dan (2) Kitab Undang-Undang Hukum Perdata (selanjutnya KUH Perdata). Jika telah sesuai dengan ketentuan pasal tersebut maka hakim dapat mengambil suatu putusan bahwa salinan itu telah memberikan alat bukti yang sempurna, sehingga terhadap dokumen elektronik yang diajukan sebagai alat bukti dapat memperkuat hakim dalam mengambil putusan tanpa harus mengadakan pembuktian lebih lanjut terhadap dokumen elektronik tersebut. ${ }^{15}$

Jika alat bukti elektronik secara formal belum diakomodasi dalam ketentuan acara perdata maka akan menyulitkan bagi hakim dalam memutus sengketa apabila para pihak mengajukan dokumen elektronik sebagai bukti. Hal itu karena sampai saat ini belum ada pengaturan yang jelas tentang kekuatan pembuatan alat bukti elektronik untuk dipersamakan dengan akta autentik. Tetapi, tidak dapat dijadikan alasan bagi hakim untuk tidak menerima, memeriksa dan memutus perkara dengan dalih undang-undangnya tidak jelas atau belum ada pengaturannya. Hal ini sesuai dengan asas yang terkandung dalam Pasal 10 Undang-Undang Nomor 48 Tahun 2009 tentang Kekuasaan Kehakiman yang menyebutkan bahwa hakim tidak boleh menolak untuk memeriksa dan memutus perkara yang diajukan kepadanya sekalipun dengan dalih hukumnya tidak jelas atau tidak ada. Dengan demikian, hakim harus tetap menerima untuk memeriksa dan memutus suatu perkara yang diajukan kepadanya sekalipun tidak ada undang-

${ }^{14}$ Ahmad S. Daud, Kebijakan Penegakan Hukum Dalam Upaya Penanggulangan Tindak Pidana Teknologi Informasi, Jurnal Lex Crimen, Volume II/No.1/Jan-Mrt/2013, hlm. 104.

${ }^{15}$ Triyanti, Kekuatan Pembuktian...Op.Cit., hlm. 28. 
undangnya, karena itu hakim harus melakukan penemuan hukum. Dengan kata lain, kekuatan bukti elektronik sebagai petunjuk sangat tergantung pada keyakinan hakim sebagai pemutus perkara. ${ }^{16}$

Dalam hukum (acara) perdata (Pasal 164 Herzien Inlandsch Reglement/HIR dan Pasal 1866 KUH Perdata) alat bukti yang sah atau diakui hukum, terdiri dari: ${ }^{17}$
a. bukti tulisan;
b. bukti dengan saksi-saksi;
c. persangkaan-persangkaan;
d. pengakuan;
e. sumpah.

Seiring perkembangan teknologi informasi dan komunikasi maka alat bukti dalam perkara perdata tidak hanya mencangkup bukti tertulis, terutama dengan dikenalnya beberapa alat bukti yang tidak diatur dalam undangundang, seperti: fotokopi, foto (potret), hasil rekaman suara maupun gambar, faks, surat elektronik (e-mail), pemeriksaan saksi menggunakan video teleconference, sistem layanan pesan singkat (sms: short massage system), dan data/dokumen elektronik lainnya. Mengenai alat-alat bukti dalam bentuk elektronik, Michael Chissick dan Akistair Kelman menjelaskan ada 3 (tiga) tipe pembuktian yang dibuat dengan komputer, yaitu ${ }^{18}$

1. Real evidence (bukti nyata) Real evidence atau bukti nyata ini meliputi kalkulasi-kalkulasi atau analisisanalisis yang dibuat oleh komputer itu sendiri melalui pengakplikasian software dan penerima informasi dari devise lain, seperti jam yang di built-in langsung dalam komputer atau remote sender. Bukti nyata ini muncul dari berbagai kondisi.

2. Hearsay evidence (bukti yang berupa kabar dari orang lain)

Adapun termasuk dalam bukti ini berupa dokumen-dokumen atau datadata yang diproduksi komputer merupakan salinan dari informasi yang diberikan (dimasukkan) oleh manusia kepada komputer.

3. Derived evidence

Alat bukti dimaksud berupa informasi yang mengkombinasikan antara bukti nyata (real evidence) dengan informasi yang diberikan oleh manusia ke komputer dengan tujuan untuk membentuk sebuah data yang tergabung, seperti membuat tagihan bank.

Akta Pejabat Pembuat Akta Tanah (PPAT) dikategorikan sebagai akta autentik, meskipun sampai saat ini belum ada perintah undangundang yang mengatur mengenai akta PPAT. Menurut Putusan Mahkamah Agung Republik Indonesia tanggal 22 Maret 1972 Nomor 937 K/ Sip/1970, bahwa akta jual beli tanah yang dilaksanakan dihadapan PPAT dianggap sebagai bukti surat yang mempunyai kekuatan bukti sempurna.

Pembuktian tulisan dilakukan dengan tulisan-tulisan autentik maupun dengan tulisantulisan di bawah tangan. ${ }^{19}$ Tulisan-tulisan

${ }^{16} /$ bid, hlm. 29.

${ }^{17}$ M. Ali Boediarto, Kompilasi Kaidah Hukum Putusan Mahkamah Agung, Hukum Acara Perdata Setengah Abad, (Jakarta: Swa Justitia, 2005), hlm. 157.

${ }^{18}$ Arsyad Sanusi M, E-Commerce Hukum dan Solusinya, (Bandung: Mizan Grafika Sarana, 2001), hlm. 97-98.

${ }^{19}$ Lihat Pasal 1867 KUH Perdata. 
autentik berupa akta autentik, yang dibuat dalam bentuk yang sudah ditentukan oleh undangundang, dibuat dihadapan pejabat-pejabat (pegawai umum) yang diberi wewenang dan di tempat akta tersebut dibuat. ${ }^{20}$ Akta autentik tidak saja dapat dibuat oleh notaris, tetapi juga oleh PPAT, ${ }^{21}$ pejabat lelang dan pegawai kantor catatan sipil. Pemberian kualifikasi sebagai pejabat umum tidak hanya kepada notaris saja, tapi juga diberikan kepada PPAT, pejabat lelang. Dengan demikian, notaris sudah pasti pejabat umum, tapi tidak setiap pejabat umum pasti notaris, karena pejabat umum bisa juga PPAT atau pejabat lelang.

Tulisan di bawah tangan atau disebut juga akta di bawah tangan dibuat dalam bentuk yang tidak ditentukan oleh undang-undang, tanpa perantara atau tidak dihadapan pejabat umum yang berwenang. ${ }^{22}$ Baik akta autentik maupun akta di bawah tangan dibuat dengan tujuan dan dipergunakan sebagai alat bukti. Dalam kenyataannya, ada tulisan yang dibuat tidak ditujukan sebagai alat bukti, tapi dapat dipergunakan sebagai alat bukti. Jika hal seperti ini terjadi maka agar mempunyai nilai pembuktian harus dikaitkan atau didukung dengan alat bukti lainnya. Perbedaan penting antara kedua jenis akta tersebut, yaitu dalam nilai pembuktian, akta autentik mempunyai pembuktian yang sempurna. Kesempurnaan akta notaris sebagai alat bukti maka akta tersebut harus dilihat apa adanya, tidak perlu dinilai atau ditafsirkan lain, selain yang tertulis dalam akta tersebut.
Akta di bawah tangan mempunyai kekuatan pembuktian sepanjang para pihak mengakuinya atau tidak ada penyangkalan dari salah satu pihak. ${ }^{23}$ Sebagai contoh Putusan Mahkamah Agung Republik Indonesia Nomor $775 \mathrm{~K} / \mathrm{Sip} / 1971$, tanggal 6 Oktober 1971, mempertimbangkan bahwa surat (surat jual beli tanah) yang diajukan dalam persidangan, kemudian disangkal oleh pihak lawan dan tidak dikuatkan dengan alat bukti lainnya maka surat tersebut dinilai sebagai alat bukti yang lemah dan belum sempurna.

Jika para pihak mengakuinya maka akta di bawah tangan tersebut mempunyai kekuatan pembuktian yang sempurna sebagaimana akta autentik. ${ }^{24}$ Tetapi, jika ada pihak tidak mengakuinya maka beban pembuktian diserahkan kepada pihak yang menyangkal akta tersebut, sedangkan penilaian penyangkalan bukti tersebut diserahkan kepada hakim. ${ }^{25}$ Baik alat bukti akta di bawah tangan maupun akta autentik keduanya harus memenuhi sahnya suatu perjanjian berdasarkan Pasal $1320 \mathrm{KUH}$ Perdata dan secara materil mengikat para pihak yang membuatnya (Pasal 1338 KUH Perdata) sebagai suatu perjanjian yang harus ditepati oleh para pihak (pacta sunt servanda).

Peradilan perdata di Indonesia menganut sistem pembuktian berdasar pada asas negatif wettelijk bewijsleer. Hal ini terlihat dalam Pasal 249 juncto 298 HIR yang tidak memakai sistem vrij bewijsleer dengan menitikberatkan pada keyakinan hakim belaka. Hal ini dilarang oleh undang-undang. ${ }^{26}$

\footnotetext{
${ }^{20}$ Lihat Pasal 1868 KUH Perdata.

${ }^{21} \mathrm{M}$. Ali Boediarto, Kompilasi Kaidah... Loc. Cit.

${ }^{22}$ Lihat Pasal 1874 KUH Perdata.

${ }^{23}$ M. Ali Boediarto, Kompilasi Kaidah...Op.Cit., hlm. 145.

${ }^{24}$ Lihat Pasal 1875 KUH Perdata.

${ }^{25}$ M. Ali Boediarto, Kompilasi Kaidah...Op.Cit., hlm. 136.

${ }^{26}$ Lihat Putusan Mahkamah Agung Republik Indonesia Nomor 583 K/Sip/1970 tanggal 10 Pebruari
} 1971. 
Pasal 1868 KUH Perdata merupakan sumber autensitas akta notaris dan merupakan dasar legalitas eksistensi akta notaris dengan syarat-syarat sebagai berikut:

a. Akta itu harus dibuat oleh (door) atau dihadapan (ten overstaan) seorang pejabat umum.

b. Akta itu harus dibuat dalam bentuk yang ditentukan oleh undang-undang.

c. Pejabat umum oleh atau dihadapan siapa akta itu dibuat, harus mempunyai wewenang untuk membuat akta tersebut.

Pasal 38 UUJN-P mengatur mengenai bentuk dan sifat akta, dengan ketentuan:

(1) Setiap akta notaris terdiri atas:

a. awal akta atau kepala akta;

b. badan akta; dan

c. akhir atau penutup akta.

(2) Awal akta atau kepala akta memuat:

a. judul akta;

b. nomor akta;

c. jam, hari, tanggal, bulan, dan tahun; dan

d. nama lengkap dan tempat kedudukan notaris.

(3) Badan akta memuat:

a. nama lengkap, tempat dan tanggal lahir, kewarganegaraan, pekerjaan, jabatan, kedudukan, tempat tinggal para penghadap dan/atau orang yang mereka wakili.

b. keterangan mengenai kedudukan bertindak penghadap.

c. isi akta yang merupakan kehendak dan keinginan dari pihak yang berkepentingan dan

d. nama lengkap, tempat dan tanggal lahir, serta pekerjaan, jabatan, kedudukan, dan tempat tinggal dari tiap-tiap saksi pengenal.
(4) Akhir atau penutup akta memuat:

a. uraian tentang pembacaan akta sebagaimana dimaksud dalam Pasal 16 Ayat (1) huruf I atau Pasal 16 Ayat (7).

b. uraian tentang penandatanganan dan tempat penandatanganan atau penerjemahan akta apabila ada.

c. nama lengkap, tempat dan tanggal lahir, pekerjaan, jabatan, kedudukan, dan tempat tinggal dari tiap-tiap saksi akta dan

d. uraian tentang tidak adanya perubahan yang terjadi dalam pembuatan akta atau uraian tentang adanya perubahan yang dapat berupa penambahan, pencoretan, atau penggantian.

(5) Akta notaris pengganti dan pejabat sementara notaris, selain memuat ketentuan sebagaimana dimaksud pada Ayat (2), Ayat (3), dan Ayat (4), juga memuat nomor dan tanggal penetapan pengangkatan, serta pejabat yang mengangkatnya.

Akta notaris bisa dibuat karena ada permintaan para penghadap (mereka) yang datang kehadapan notaris. Penghadap yang meminta dibuatkan akta harus menghadap dan menyatakan kehendaknya dihadapan notaris. Dalam praktik notaris, banyak ragam kalimat dipergunakan pada awal kata, yaitu tentang menghadap, misalnya kalimat:

1. Menghadap kepada saya...

2. Menghadap dihadapan saya...

3. Berhadapan dengan saya...

4. Telah hadir dihadapan saya...

5. Hadir dihadapan saya...

Untuk memperoleh penjelasan arti kalimat tersebut penulis kemukakan pendapat Tan Thong Kie bahwa: ${ }^{27}$

- Bahwa kalimat menghadap tersebut merupakan terjemahan dari verscheen voor mij...notaris ter standplaats... 
- Adapun yang mencolok berbagai terjemahan kata verscheen, kata kerjanya adalah verschijnen. Menurut penulis kata Belanda verschijne mempunyai arti "datang dan menghadap", unsur "datang" itu ada. Demikian juga terjemahannya dalam bahasa Indonesia "menghadap". Orang yang menghadap merupakan orang yang datang. Padahal praktik notaris tidak selalu demikian, misalnya seseorang sakit keras dan tidak dapat datang, sehingga apabila diminta maka notaris yang datang. Dalam hal ini apakah orang sakit itu verschijnt? Contoh lain apabila notaris diminta membuat berita acara rapat yang diadakan di luar kantor notaris. Notaris yang datang, bukan para pemegang saham yang biasanya sudah menunggu dalam ruangan. Inilah pertanyaan yang pernah dikemukakan penulis kepada seorang pendidik yang bernama Broekx di Breda, Belanda. Guru yang telah menghasilkan banyak kandidat notaris dinegaranya itu tidak setuju dengan adanya unsur datang dalam kata verschijnen. la mengatakan "saya tidak setuju dengan pendapat saudara”. Kata verschijnen harus dilihat dalam arti yuridisnya (Pasal 24, 25, dan 28 PJN), jadi tidak dalam arti yang diberikan oleh masyarakat. Verschijnen adalah kehadiran nyata (waarneembaar tegenwoordig zijn) dan dalam hal itu tidak dipedulikan siapa yang datang, pelanggan atau notaris".
- Jawaban ini juga tidak memuaskan penulis yang pekerjaannya langsung mengganti kata "menghadap" dengan kata "berhadapan".

- Dengan memakai kata terakhir ini jelaslah bahwa notaris dan penghadap sama-sama berhadapan dan ini yang terpenting untuk suatu akta autentik.

- Ternyata dalam bahasa Indonesia kata "menghadap" juga dapat menimbulkan kesulitan lain. Kata itu dianggap oleh sementara orang meliputi arti bahwa kedudukan dan status orang yang menghadap lebih rendah dari pada notaris. Anggapan ini mungkin beralasan untuk beberapa golongan, namun sebenarnya hal itu tidak harus dipersoalkan, sebagai public servant seorang notaris harus datang di tempat jasanya dibutuhkan, baik dikantornya maupun di rumah sakit atau di tempat lain. Anjuran penulis di bawah ini mungkin dapat mengatasi kesulitan ini.

- Di Belanda kata verscheen selalu dipakai, apakah soal, seperti tertulis di atas pernah dipersoalkan, tidak diketahui.

- Di Indonesia penulis menganjurkan memakai salah satu dari kata-kata: "hadir" atau "berhadapan" dan dengan memakai salah satu dari 2 kata ini tidak dipersoalkan siapa yang datang, notaris atau penghadap, dan juga tidak mengandung anggapan sementara orang bahwa kedudukan orang yang menghadap lebih rendah dari pada notaris.

${ }^{27}$ Tan Thong Kie, Studi Notariat \& Serba-serbi Praktek Notaris, (Jakarta: Ichtiar Baru Van Hoeve, 2007), hlm. 488-489. 
Berdasarkan uraian di atas pengaturan notaris Indonesia berdasarkan UUJN/UUJN-P dan peraturan perundang-undangan lainnya mengatur bahwa penghadap dalam arti fisik kertas (secara fisik tanpa media apapun ada dihadapan notaris). Dengan demikian, dokumen yang diperlukan masih harus diperlihatkan fisiknya. ${ }^{28}$ Merujuk pendapat Edmon Makarim hal seperti ini ciri notaris konvensional. Meskipun jabatan notaris telah berjalan sejak lama, bahkan sejak masa Hindia Belanda, namun dalam praktiknya masih dijumpai beberapa kendala yang harus dihadapi notaris dalam menjalankan tugasnya kepada publik sebagai berikut:

1. Keterbatasan ruang penyimpanan akta dan jumlah notaris.

2. Pelanggaran profesionalitas notaris terkait syarat keatutentikan.

3. Lemahnya bukti pendukung keautentikan identitas subjek hukum.

4. Benturan kepentingan notaris dalam pembuatan akta.

5. Pelanggaran kerahasiaan.

6. Pertanggungjawaban pajak.

7. Lemahnya kendali penelusuran dan pembinaan instansi terkait.

Konsep notaris mayantara (ataupun cyber notary) menghendaki notaris dalam menjalankan tugas atau kewenangannya (jabatannya) berbasis teknologi informasi khususnya dalam pembuatan akta. ${ }^{29}$ Dalam konsep ini, bahwa menghadap secara fisik atau langsung berhadapan tidak diperlukan, tetapi bisa menggunakan media pandang dengar, (seperti teleconfrence atau skype) tanpa batas wilayah negara (borderless) ataupun batas kota/provinsi. Dalam penelitian Fahma Rahman Wijanarko dijelaskan cyber notary merupakan suatu konsep notaris yang menjalankan fungsi dengan mengaplikasikan ke dalam transaksi atau hubungan secara elektronik melalui internet sebagai media utama dalam kinerjanya untuk membuat suatu akta dan mengarah pada bentuk akta yang awalnya sah apabila tertuang dalam kertas, menuju ke akta secara elektronik (akta elektronik) atau dalam bentuk dokumen elektronik. ${ }^{30}$

Dalam konsep ini, notaris bisa membuat akta tanpa harus berhadapan langsung secara fisik. Klien tidak perlu datang ke kantor notaris, akan tetap dilayani dalam membuat akta tanpa batas wilayah dalam konteks lokal, regional, nasional bahkan antarnegara. Dalam pengembangan lebih lanjut, identitas diri penghadap tidak perlu diperlihatkan secara fisik, tetapi notaris bisa mengunduhnya dari instansi yang berwenang membuat/mengeluarkan identitas tersebut, misalnya Kartu Tanda Penduduk (KTP), Kartu Keluarga (KK), Akta/ Surat Nikah atau identitas lainnya yang diperkenakan diunduh dengan menggunakan kode akses tertentu. Demikian pula dokumen yang diperlukan dalam pembuatan akta tersebut cukup diunduh notaris dari instansi tertentu.

Pada sisi lain para penghadap, saksi dan notaris cukup menggunakan tanda tangan, meterai dan stempel secara digital. ${ }^{31}$ Bahkan diperlukan pula sidik jari digital, hal ini untuk memenuhi ketentuan Pasal 16 Ayat (1) huruf c

${ }^{28}$ Edmon Makarim, Notaris \& Transaksi Elektronik, Kajian Hukum tentang Cybernotary atau Electronic Notary, (Jakarta: RajaGrafindo Persada, 2013), hlm. 138-139.

${ }^{29}$ R.A. Emma Nurita, Cyber Notary (Pemahaman Awal dan Konsep Pemikiran), (Bandung: Refika Aditama, 2012), hlm. 4.

${ }^{30}$ Fahma Rahman Wijanarko, Tinjauan Yuridis...Op.Cit., hlm. 8.

${ }^{31}$ Edmon Makarim, Notaris \& Transaksi... Op. Cit., hlm. 128-129. 
UUJN-P bahwa notaris wajib melekatkan surat dan dokumen serta sidik jari penghadap pada minuta akta. Media penyimpanan minuta dan salinanpun pun tidak perlu dalam bentuk kertas, tetapi disimpan dalam microchip atau microfilm atau media lainnya yang dapat dicetak sesuai keperluan. Jika hal tersebut bisa dilakukan maka kantor notaris tidak memerlukan ruangan yang besar. ${ }^{32}$

Penelitian Fahma Rahman Wijarno, menyinggung kekuatan autentik akta notaris terhadap pemberlakuan cyber notary. Menurutnya "akta tersebut tidak memiliki pembuktian sempurna layaknya akta autentik, karena tidak memenuhi syarat keautentikan suatu akta, dengan alasan:

1. Akta autentik ditentukan oleh undangundang dan hingga saat ini belum ada peraturan perundang-undangan yang mengatur secara khusus yang menyatakan bahwa akta autentik dapat dibuat secara elektronik (akta elektronik).

2. Mengenai tanda tangan, akta autentik harus ditandatangani oleh para pihak, saksi-saksi, dan notaris, namun hingga saat ini belum ada peraturan perundang-undangan yang menyatakan bahwa tanda tangan digital boleh digunakan dalam akta autentik.

3. Pada dasarnya dalam pembuatan akta autentik, para pihak harus hadir secara fisik dihadapan notaris dan disaksikan oleh para saksi, untuk selanjutnya dibacakan oleh notaris dihadapan para pihak dan para saksi. Kemudian akta ditandatangani oleh para pihak, saksisaksi dan oleh notaris. Namun, hingga saat ini belum ada peraturan perundang-undangan yang menyatakan bahwa konsep berhadapan boleh melalui media telekonferensi" ${ }^{33}$

Konteks terkini tidak dapat dipungkiri dalam perkembangan teknologi informasi dan komunikasi terdapat beberapa moda teknologi dari suatu tanda tangan elektronik, yaitu

1. Penggunaan kata kunci (password) ataupun kombinasinya (hybrid methods).

2. Tanda tangan yang dipindai secara elektronik (scanned signatures) atau pengetikan nama pada suatu informasi (typed names).

3. Penggunaan fitur tombol tanda persetujuan atau tanda penerimaan secara elektronik (ok button atau accept button) yang ditunjang dengan saluran komunikasi yang aman (secure socket layer).

4. Penggunaan tanda yang unik pada anggota badan (biometrik).

5. Penggunaan tanda tangan digital yang berbasiskan enkripsi suatu pesan (digital signatures)

Dalam perkembangan dibeberapa negara telah menghapuskan adanya persyaratan tentang segel (seal) pada transaksi atas tanah yang dianggap sudah tidak relevan dalam konteks saat ini. Hal tersebut telah digantikan dengan keberadaan suatu tanda tangan dari pihak ketiga yang menjalankan fungsi kesaksian (attestation/witnessed). Beberapa negara (contoh: Irlandia) telah memiliki peraturan yang memungkinkan suatu tanda tangan elektronik yang aman (secured esignature) untuk menggantikan peranan segel.

\footnotetext{
${ }^{32} \mathrm{Ibid}$.

${ }^{33}$ Fahma Rahman Wijanarko, Tinjauan Yuridis...Op.Cit., hIm. 14.
} 
Sejumlah negara bahkan telah meluncurkan inisiatif yang memfasilitasi penggunaan dokumen elektronik dan tangan tangan elektronik dalam transaksi tanah (contoh: Belanda, Belgia, dan Jerman). Dalam undangundang beberapa negara juga diberikan kemungkinan penggunaan "segel elektronik" (electronic seals) sebagai alternatif dari segel manual (manual seal) yang diakui secara resmi, sedangkan rincian detail teknis dari bentuk segel elektronik diatur secara terpisah (contoh: Inggris, Australia, dan Amerika).

Uraian di atas merupakan gambaran ideal dari konsep notaris mayantara. Dalam konsep ini, bukan hanya tanda tangan yang harus dilakukan secara elektronik, tetapi juga dokumen yang diperlukan dalam membuat akta. Secara sederhana bahwa konsep tersebut dapat dipergunakan dalam pelaksanaan RUPS, yaitu dalam Pasal 77 Ayat (1) Undang-Undang Perseroan Terbatas (UUPT), meskipun dalam hal ini secara teknis belum ada dasar hukumnya. Tetapi, hal ini terbatas hanya untuk media saling pandang dalam kehadiran RUPS perseroan terbatas yang belum menggambarkan secara menyeluruh wujud dari konsep notaris mayantara.

Dalam UUPT Pasal 77 Ayat (1) UUPT ditegaskan bahwa selain penyelenggaraan RUPS sebagaimana dimaksud Pasal 76 , RUPS dapat dilakukan melalui media telekonferensi, video konferensi, atau sarana media elektronik lainnya yang memungkinkan semua peserta saling melihat dan mendengar secara langsung serta berpartisipasi dalam rapat. Dalam Penjelasan Pasal 77 Ayat (4) yang dimaksud dengan disetujui dan ditandatangani adalah disetujui dan ditandatangani secara fisik atau secara elektronik. Selama ini, jika sebuah perseroan terbatas melakukan RUPS dilakukan secara konvensional, yaitu para penghadap, para saksi dan notaris harus berada di tempat dan waktu yang sama dan hadir secara fisik dihadapan notaris (Pasal 76 UUPT). Berdasarkan Pasal 77 Ayat (1) UUPT maka RUPS dapat dilakukan di luar ketentuan Pasal 76 UUPT.

Ketentuan Pasal 77 Ayat (1) UUPT juncto Penjelasan Pasal 77 Ayat (4) UUPT telah membuka era baru dalam dunia notaris. Setidaknya era notary by digital pada bidang tertentu yang diperkenankan oleh hukum. Meskipun dalam hal ini masih diperlukan tindakan lebih lanjut, misalnya pemerintah dan organisasi jabatan notaris segera membuat aturan mengenai teknis pelaksanaan RUPS melalui media elektronik tadi. Kenyataannya sekarang ini media elektronik sudah dipergunakan oleh para notaris untuk proses pengesahan perseroan terbatas sebagai badan hukum dan hal lainnya yang berkaitan melalui Sistem Administrasi Badan Hukum (SABH).

Menurut Pasal 1 angka 1 dan 4 UU ITE menegaskan: angka 1 Informasi elektronik adalah satu atau sekumpulan data elektronik, termasuk tetapi tidak terbatas pada tulisan, suara, gambar, peta, rancangan, foto, electronic data interchange (EDI), surat elektronik (electronic mail), telegram, teleks, telecopy atau sejenisnya, huruf, tanda, angka, kode akses, simbol, atau perforasi yang telah diolah yang memiliki arti atau dapat dipahami oleh orang yang mampu memahaminya. Angka 4 dokumen elektronik adalah setiap informasi elektronik yang dibuat, diteruskan, dikirimkan, diterima, atau disimpan dalam bentuk analog, digital, elektromagnetik, optikal, atau sejenisnya, yang dapat dilihat, ditampilkan, dan/atau didengar melalui komputer atau sistem elektronik termasuk, tetapi tidak terbatas pada tulisan, suara, gambar, peta, rancangan, foto atau sejenisnya, huruf, tanda, angka, kode akses, 
simbol atau perforasi yang memiliki makna atau arti atau dapat dipahami oleh orang yang mampu memahaminya. Pasal 1 angka $12 \mathrm{UU}$ ITE menegaskan bahwa tanda tangan elektronik adalah tanda tangan yang terdiri atas informasi elektronik yang dilekatkan, terasosiasi atau terkait dengan informasi elektronik lainnya yang digunakan sebagai alat verifikasi dan autentikasi.

Dalam perkembangan berikutnya penggunaan media elektronik tidak hanya untuk melaksanakan ketentuan Pasal 77 Ayat (1) UUPT juncto Penjelasan Pasal 77 Ayat (4) UUPT, tapi mungkin juga untuk tindakan hukum lainnya, karena yang penting ada dasar hukum untuk melaksanakannya. Sepanjang dasar hukumnya belum ada maka tidak dapat dilaksanakan, kecuali untuk melaksanakan ketentuan Pasal 77 Ayat (1) UUPT juncto Penjelasan Pasal 77 Ayat (4) UUPT. Dengan demikian, kendala untuk mewujudkan dan menerapkan konsep notaris mayantara, yaitu

1. Pada UUJN/UUJN-P sendiri yang masih mengatur bahwa bahwa menghadap masih harus dilakukan secara fisik, dan tidak memberi ruang bisa menghadap menggunakan media pandang dengar-interaktif, seperti telekonferensi atau video conference atau skype atau bentuk lainnya yang secara teknologi informasi bisa dilakukan.

2. Belum ada pengaturan tentang penggunaan materai elektronik dan stempel notaris elektronik serta sidik jari elektronik.

3. Belum ada institusi yang berwenang untuk melakukan authentification tanda tangan bagi warga negara Indonesia atau mereka yang akan bertransaksi secara elektronik.

4. Belum ada pengaturan (yang membolehkan notaris) mengunduh identitas subjek penghadap secara terbatas (dengan kode akses) tertentu dalam kepentingan pembuatan akta.

Untuk mengatasi hal tersebut seharusnya dilakukan perubahan UUJN/UUJN-P yang menjadi dasar hukum notaris Indonesia dan peraturan perundang-undangan lainnya dalam rangka menunjang pelaksanaan notaris mayantara menghadapi persaingan global.

\section{Kesimpulan}

Konsep notaris mayantara ataupun cyber notary menghendaki notaris dalam menjalankan tugas atau kewenangannya berbasis teknologi informasi khususnya dalam pembuatan akta. Dalam konsep ini, bahwa menghadap secara fisik atau langsung berhadapan tidak diperlukan. Tetapi, bisa menggunakan media pandang dengar, tanpa batas kota/provinsi bahkan tanpa batas wilayah negara (borderless). Dengan konsep ini, tidak perlu menghadap langsung dengan cara datang ke kantor notaris. Dalam pengembangan lebih lanjut, identitas diri penghadap tidak perlu diperlihatkan secara fisik, tapi cukup dengan cara mengunduhnya. Demikian pula dokumen yang diperlukan dalam pembuatan akta cukup diunduh notaris dari instansi tertentu. Pada sisi lain untuk para penghadap, saksi dan notaris cukup menggunakan tanda tangan, meterai dan stempel secara digital. Bahkan diperlukan pula sidik jari digital. Hal ini merupakan gambaran ideal dari konsep notaris mayantara. Dalam konsep ini, bukan hanya tanda tangan yang harus dilakukan secara elektronik, tapi juga dokumen dalam membuat akta. 


\section{Saran}

Terkait kendala untuk mewujudkan dan menerapkan konsep notaris mayantara disarankan perubahan dilakukan terhadap UUJN/UUJN-P yang menjadi dasar hukum notaris Indonesia dan peraturan perundangundangan lainnya dalam rangka menunjang pelaksanaan notaris mayantara menghadapi persaingan global.

\section{Referensi}

Ahmad Crusade Giri Brata. 2014. Analisis Konsep Notaris Mayantara dan Otentisitas Aktanya Terkait UndangUndang Nomor 40 Tahun 2007 tentang Perseroan Terbatas. Tesis. Program Pascasarjana Program Magister Kenotariatan, Universitas Dipenogoro.

Ahmad S. Daud. Kebijakan Penegakan Hukum Dalam Upaya Penanggulangan Tindak Pidana Teknologi Informasi. Jurnal Lex Crimen. Volume II/No.1/Jan-Mrt/2013.

Arsyad Sanusi M. 2001. E-Commerce Hukum dan Solusinya. Bandung: Mizan Grafika Sarana.

Bagir Manan. 2004. Hukum Positif Indonesia. Yogyakarta: UII Press.

Edmon Makari. 2013. Notaris \& Transaksi Elektronik, Kajian Hukum tentang Cybernotary atau Electronic Notary, Jakarta: RajaGrafindo Persada.

Fahma Rahman Wijanarko. Tinjauan Yuridis Pemberlakuan Cyber Notary di Indonesia Berdasarkan Undang-Undang Nomor 2 Tahun 2014 tentang Perubahan atas Undang-Undang Nomor 30 Tahun 2004 tentang Jabatan Notaris. Jurnal
Repertorium. Volume 2. Nomor 2. Tahun 2015.

George Whitecross Patton. 1953. A TextBook of Jurisprudence. Oxford: at the Clarendon Press.

Komang Febrinayanti Dantes. 2015. Kekuatan Hukum Akta Notaris Berkenaan dengan Penandatanganan Rapat Umum Pemegang Saham (RUPS) Perseroan Terbatas Melalui Media Telekonferensi. Tesis. Universitas Udayana.

M. Ali Boediarto. 2005. Kompilasi Kaidah Hukum

Putusan Mahkamah Agung, Hukum

Acara Perdata Setengah Abad. Jakarta:

Swa Justitia.

Panos Briefing. Globalization and Employment, New Opportunities. Real Threats. London Nomor 33. May 1999.

Philipus M. Hadjon. Tentang Wewenang. Jurnal Yuridika. Fakultas Hukum Universitas Airlangga. Nomor 5 dan 6 . Tahun XII. September-Desember 1997.

R.A. Emma Nurita. 2012. Cyber Notary (Pemahaman Awal dan Konsep Pemikiran). Bandung: Refika Aditama. Tan Thong Kie. 2007. Studi Notariat \& Serbaserbi Praktek Notaris. Jakarta: Ichtiar Baru Van Hoeve.

Tiska Sundani. Analisis Hukum atas Penggunaan dan Pembuatan Akta Notaris Secara Elektronik. Premise Law Jurnal. Volume 1. Tahun 2017.

Triyanti. Kekuatan Pembuktian Dokumen Elektronik Sebagai Pengganti Minuta Akta Notaris. Jurnal Repertorium. Volume II. Nomor 2 Juli - Desember 2015. 